\title{
ROLA EUNUCHÓW NA DWORZE CESARZY BIZANTYŃSKICH Przypadek Narzesa
}

Eunuchowie to kasta, która funkcjonowała na dworach władców w starożytności na obszarze niemal całego Bliskiego i Dalekiego Wschodu. Dostrzegamy ich obecność w Mezopotamii już w drugim tysiącleciu prz. Chr. i w Egipcie w okresie panowania faraonów XIX dynastii w XIV w. prz. Chr. Na dworze chińskich cesarzy natomiast służyli już w XII w. przed Chrystusem ${ }^{1}$. Źródła wspominają także o ich działalności w otoczeniu królów i władców imperium asyryjskiego w okresie od X do VII w. prz. Chr. i na dworze perskim ${ }^{2}$. Zwyczaj posiadania eunuchów na dworze został przyjęty w późniejszym okresie również przez władców chrześcijańskich na obszarze Bizancjum i w krajach, gdzie panował islam ${ }^{3}$. Warto w tym miejscu dodać, że eunuchowie funkcjonowali jako specyficzna grupa społeczna również na dworze władców Imperium Ottomańskiego i na Dalekim Wschodzie aż do XX wieku ${ }^{4}$. Kathryn M. Ringrose twierdzi wręcz, że rzezańcy stali się stałym elementem społeczeństw w wielu państwach, a nawet ryzykuje opinię, że zapewniali oni stabilność owych społeczeństw5

* Mgr Rajmund Malinowski - doktorant przy Katedrze Historii Starożytnej i Bizantyńskiej w Instytucie Historii na Wydziale Nauk Humanistycznych Katolickiego Uniwersytetu Lubelskiego Jana Pawła II; e-mail: rajmundmalinowski@interia.pl.

${ }^{1}$ Por. W. Szumowski, O eunuchach i kastracji w różnych krajach i czasach oraz kilka drobnych artykułów, Kraków 1946, 20-21; F. Jonckheere, L'Eunuque dans l'Égypte pharaonique, „Revue d'Histoire des Sciences" 7 (1954) 139-155; S.H. Tsai, The Eunuchs in the Ming Dynasty, New York 1996.

${ }^{2}$ Por. L.A. Coser, The political Functions of Eunuchism, „American Sociological Review” 6 (1964) 880.

${ }^{3}$ Por. K. Hopkins, Eunuchs in Politics in the Later Roman Empire, „Cambridge Classical Journal” 9 (1963) 62-80; L. Cilliers - F.P. Retief, The Eunuchs of Early Byzantium, „Scholia” 13 (2004) 108-117; N.M. El-Cheikh, Servants at the Gate: Eunuchs at the Court of Al-Muqtadir, „Journal of the Economic and Social History of the Orient" 48 (2005) 234-252; L. Tracy, Introduction: A History of Calamites: The Culture of Castration, w: Castration and Culture in the Middle Ages, ed. L. Tracy, Cambridge 2013, 6.

${ }^{4}$ Por. E.R. Toledano, The Imperial Eunuchs of Istanbul: From Africa to the Heart of Islam, „Middle Eastern Studies” 20 (1984) 379-390; K. Ringrose, The Perfect Servant: Eunuchs and the Social Construction of Gender in Byzantium, Chicago 2003, 8.

${ }^{5}$ Por. K. Ringrose, Eunuchs in Historical Perspective, „History Compass” 5 (2007) 495. 
W ostatnich latach nastąpił znaczny rozwój badań nad rolą eunuchów w systemie władzy i administracji poszczególnych państw zarówno starożytnych, jak i nowożytnych. Ten trend jest związany bezpośrednio ze zmianą sposobu postrzegania roli eunuchów $\mathrm{w}$ różnych społeczeństwach. Zmiana ta ma $\mathrm{z}$ kolei związek z nowymi kierunkami studiów w ramach tak zwanych gender studies ${ }^{6}$.

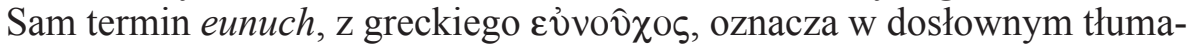
czeniu osobę, która jest strażnikiem łoża lub sypialni ${ }^{7}$. Wyrażenie to odnosi się do człowieka wykastrowanego ${ }^{8}$, który nie jest w stanie posiadać potomstwa lub też z jakiegoś innego powodu nie może uczestniczyć $\mathrm{w}$ procesie prokreacji, na przykład z powodu impotencji lub braku aktywności seksualnej. Ta z kolei mogła być spowodowana złożeniem przez daną osobę rodzaju przysięgi, która nakazywała jej zachowanie czystości. Mogła ona mieć formę celibatu lub też innej obietnicy niekoniecznie o charakterze religijnym. W odniesieniu do tych osób, które same podjęły decyzję o seksualnej wstrzemięźliwości lub też urodziły się z niewykształconymi organami rozrodczymi, używamy terminu „naturalny eunuch” lub „eunuch z natury”. Najczęściej jednak słowo eunuch jest używane w odniesieniu do mężczyzn, którzy zostali pozbawieni narządów rozrodczych. Tych z kolei można podzielić na trzy grupy. Pierwszą z nich stanowili autokastraci. Byli to dorośli mężczyźni, którzy dokonywali na sobie tego zabiegu, głównie z pobudek religijnych. Zabieg ten był bardzo często sam w sobie elementem kultu. Człowiek, który się mu poddawał zostawał „naznaczony” i mógł sprawować funkcję kapłana. Tacy eunuchowie, nazywani galli, szczególnie często byli spotykani na obszarze starożytnej Anatolii i w Indiach ${ }^{10}$. Autokastraci byli także obecni w tradycji chrześcijańskiej ${ }^{11}$. Być

${ }^{6}$ Por. tamże, s. 495.

${ }^{7}$ Por. Ringrose, The Perfect Servant, s. 16.

${ }^{8}$ Kastracje przeprowadzane w starożytności mogły być zupełne lub niezupełne. Kastracja zupełna polegała na odcięciu zarówno prącia jak i jąder. Osoba, która była poddawana takiemu zabiegowi całkowicie traciła zdolność spółkowania i płodzenia potomstwa. Podczas przeprowadzania kastracji niezupełnej odcinane były tylko jądra, a trzebieńcy jej poddawani w wielu przypadkach zachowywali zdolność spółkowania, pomimo całkowitej utraty zdolności prokreacyjnych. Więcej na temat technik kastracji por. Szumowski, O eunuchach i kastracji, s. 5; Ringrose, Eunuchs, s. 497.

${ }^{9}$ Wśród bizantyńskiego kleru istniało przekonanie, że osoby, które urodziły się z niewykształconymi narządami rozrodczymi lub posiadały zaburzenia hormonalne zostały uwolnione za sprawą interwencji boskiej od pokusy grzechu nieczystości, por. Ringrose, Eunuchs, s. 496.

${ }^{10}$ Praktyka poddawania się zabiegowi autokastracji miała na obszarze starożytnej Anatolii i Frygii charakter rytualny i była związana z kultem Kybele, bogini płodności i urodzaju. Zabieg wykonywali na sobie kapłani, którzy często służyli jako strażnicy kapliczek, por. Szumowski, O eunuchach $i$ kastracji, s. 7; W. Stevenson, The Rise of Eunuchs in Greco-Roman Antiquity, „Journal of the History of Sexuality" 5 (1995) 498-499; L.E. Roller, The Ideology of the Eunuch Priest, „Gender \& History” 9 (1997) 542-555; Ringrose, The Perfect Servant, s. 9; S. Tougher, The Eunuch in Byzantine History and Society, London 2008, 10.

${ }^{11}$ Por. D.F. Caner, The Practice and Prohibition of Self-castration in Early Christianity, VigCh 51 (1997) 396-415; Tougher, The Eunuch in Byzantine History and Society, s. 10. 
może należał do nich m.in. Orygenes (ok. 185-254) ${ }^{12}$. Drugą grupę stanowili mężczyźni, niewolnicy, którzy byli poddawani kastracji w młodym wieku, bardzo często przez członków własnych rodzin. Było to działanie podejmowane z pełną premedytacja, a w grę wchodził tutaj czynnik handlowo-zarobkowy. Młodzieńcy byli poddawani kastracji w celu przygotowania ich do sprawowania funkcji eunucha na dworze władcy lub zamożnego pana i stosunkowo łatwo dochodzili do takich stanowisk. Trzecią kategorię stanowili mężczyźni, na których przeprowadzono ten zabieg już w wieku dojrzałym. Ci jednak byli uważani za mniej „cennych” z uwagi na istotne zmiany hormonalne, które zaszły w ich ciele w okresie dojrzewania. Do tej grupy można zaliczyć m.in. przestępców i jeńców wojennych, w przypadku których przeprowadzany zabieg był formą kary. W cesarstwie rzymskim kastracją karano ludzi, którym udowodniono pederastię i stosunki płciowe ze zwierzętami ${ }^{13}$. Wytrzebienie było też metodą pozbywania się przeciwników politycznych ${ }^{14}$.

W przypadku eunuchów, którzy przebywali na dworze bizantyjskim podział wygląałał nieco inaczej. Wśród nich wyróżniano dwie grupy. Pierwszą

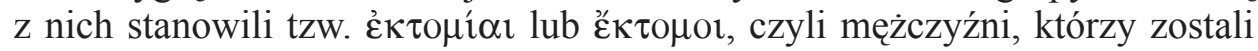
poddani chirurgicznym zabiegom mającym na celu pozbawienie ich wszelkich

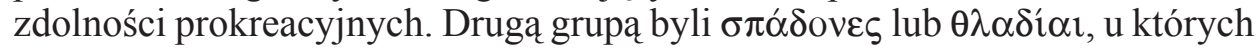
prokreacja była niemożliwa $\mathrm{z}$ uwagi na chorobę lub impotencję ${ }^{15}$.

Eunuchowie spełniali rozmaite funkcje na dworach władców i królów. Najczęściej występowali w roli osób sprawujących pieczę nad haremami lub też pełnili funkcję nadwornych szambelanów ${ }^{16}$. Byli również bardzo pożądani w roli służących, posłów oraz agentów. Fakt, że byli „naznaczeni” pozwalał im sprawnie poruszać się i funkcjonować zarówno wśród różnych klas społecznych, jak i w środowiskach zdominowanych przez płeć żeńską. Bardzo istotnym elementem, który podnosił zapotrzebowanie na eunuchów na dworach był fakt, że nie mogli oni posiadać potomstwa. W ten sposób władcy nie musieli się obawiać, że któryś z kastratów zbuntuje się i przejmie pełnię władzy, zakładając nową dynastię. $Z$ tego powodu m.in. eunuchowie byli

${ }^{12}$ Na pytanie, czy Orygenes rzeczywiście dokonał na sobie zabiegu kastracji, stara się odpowiedzieć w swoim artykule Mariusz Szram (Autokastracja Orygenesa - fakt czy nieporozumienie?, VoxP 23 (2003) t. 44-45, 171-202).

${ }^{13}$ Por. Szumowski, O eunuchach i kastracji, s. 24.

${ }^{14}$ Por. tamże, s. 25; J. Herrin, Bizancjum. Niezwykłe dziedzictwo średniowiecznego imperium, thum. N. Radomski, Poznań 2009, 201.

${ }^{15}$ Por. R. Guilland, Les eunuques dans l'Empire Byzantin: Étude de titulature et de prosopographie byzantines, EtByz 1 (1943) 201. Nieco inny podział proponuje Walter Stevenson (The Rise of Eunuchs, s. 497-498), który w swoim artykule rozróżnia trzy kategorie rzezańców funkcjonujące w rzymsko-greckim świecie: 1) tych, którzy urodzili się z niewykształconymi organami rozrodczymi; 2) tych, którzy zostali „częściowo” wykastrowani; 3) tych, których całkowicie wytrzebiono.

${ }^{16}$ Szambelan - osoba będąca wysokim urzędnikiem na dworze króla, albo władcy. Funkcje, które sprawowali szambelani różniły się w zależności od epoki i państwa, w którym taki urząd istniał, por. E. Lalou, Chambellan, w: Lexikon des Mittelalters, II, München 1983, 1671. 
obdarzani dużym zaufaniem i często otrzymywali eksponowane stanowiska i ważne zadania. Inną funkcją, którą im powierzano, był nadzór nad wychowaniem i edukacją młodych książąt, co pozwalało im na wchodzenie w bliższe relacje z przyszłymi władcami i nierzadko na manipulowanie nimi ${ }^{17}$. W niektórych krajach Bliskiego Wschodu rola rzezańców w aparacie biurokratycznym w pewnym okresie była tak wielka, że słowo eunuch było używane jako synonim urzędnika bądź dworskiego ministra ${ }^{18}$.

W Imperium Romanum stosunek do rzezańców ulegał zmianie na przestrzeni wieków. Początkowo przeprowadzanie zabiegów kastracji w celu pozyskiwania eunuchów było zakazane przez prawo ${ }^{19}$. Obostrzenia i rygorystyczne przepisy w tej materii zostały wprowadzone w I-II w., za panowania dwóch cesarzy, Domicjana (81-96) i Hadriana (117-138) ${ }^{20}$. Prawo to było naginane lub omijane przez rzymskich arystokratów, którzy sprowadzali eunuchów z odległych krajów, w których kastracja nie była zakazana. Tacy młodzi chłopcy, sprowadzani jako niewolnicy, byli bardzo kosztowni.

1. Eunuchowie w systemie politycznym Bizancjum. W późniejszym okresie prawo dotyczące eunuchów uległo znacznej liberalizacji, a z usług trzebieńców zaczęli korzystać także sami cesarze. Wiemy, że służyli oni na dworze Konstantyna Wielkiego (306-337) i Konstancjusza II (337-361), ale nie byli w tym okresie grupą zbyt liczną. Potrafili jednak dochodzić do bardzo wysokich stanowisk. Przykład może tu stanowić niejaki Euzebiusz, który w otoczeniu Konstancjusza dzierżył zaszczytną funkcję praepositus sacri cubiculi ${ }^{21}$. Mimo, że kolejni cesarze, tacy jak Leon I (457-474) i Justynian I (527-565), zaostrzyli prawo wobec osób, które przeprowadzały i poddawały się zabiegowi kastracji $i^{22}$, to jednak nie przeszkadzało im to w posiadaniu na swoim dworze dużej ilości eunuchów. Zyskiwali oni bardzo często sympatię władcy i mieli niejednokrotnie przemożny wpływ na niego. Ich wysoka pozycja sprawiała, że nie cieszyli się oni dobrą opinią wśród arystokratów i senatorów, którzy widzieli w nich naturalne zagrożenie dla swoich interesów ${ }^{23}$. Rzezańcy sprawowali

${ }^{17}$ Por. Coser, The Political Functions of Eunuchism, s. 880.

${ }^{18}$ Por. tamże.

${ }^{19}$ W Rzymie zabieg kastracji uchodził za niebezpieczny dla życia i w istocie taki był. W omawianym okresie przeżywalność osób poddawanych temu zabiegowi była niezwykle niska i wynosiła ok. 10\%, por. Szumowski, O eunuchach i kastracji, s. 18.

${ }^{20}$ Por. Guilland, Les eunuques dans l'Empire Byzantin, s. 198. Zob. też Stevenson, The Rise of Eunuchs, s. 499.

${ }^{21}$ Praepositus sacri cubiculi - przełożony gabinetu cesarskiego: wysoki urząd pałacowy w późnym cesarstwie rzymskim, por. H.-W. Haussig, Historia kultury bizantyńskiej, thum. T. Zabłudowski, Warszawa 1969, 61; P.S. Barnwell, Emperor, Prefects, and Kings: Roman West, 395-565, London 1992, 20.

${ }^{22}$ Por. Guilland, Les eunuques dans l'Empire Byzantin, s. 199.

${ }^{23}$ Por. Konstantynopol - Nowy Rzym. Miasto i ludzie w okresie wczesnobizantyńskim, red. M.J. Leszka - T. Wolińska, Warszawa 2011, 223-224. 
także niezwykle istotną rolę $\mathrm{w}$ dworskim ceremoniale. To oni otaczali cesarza, a nawet w jego imieniu przyjmowali posłów, którzy starali się o audiencję.

Eunuchowie, którzy służyli na dworze bizantyńskim byli głównie niewolnikami pochodzącymi z plemion zamieszkujących wybrzeże Morza Czarnego i obszar Kaukazu ${ }^{24}$. Najczęściej jako miejsce pozyskiwania młodych chłopców z przeznaczeniem służby na dworze wybierano obszar Abchazji i Paflagonii. Innym rejonem, z którego pochodzili kandydaci na eunuchów, była Armenia, Persarmenia i wyspy greckie ${ }^{25}$. Praktyka sprowadzania stamtąd małoletnich osób była bardzo żywa nawet wówczas, gdy władze oficjalnie zabroniły tego procederu. Chłopcy oddzieleni od swoich rodziców i najbliższych musieli zapomnieć o przeszłości i miejscu, z którego pochodzili. Rozpoczynali bowiem zupełnie nowe życie w nowym środowisku i z nowym panem ${ }^{26}$.

Funkcje, które sprawowali eunuchowie na bizantyńskim dworze, nie różniły się w znacznym stopniu od tych, które sprawowali rzezańcy na dworach innych państw Dalekiego i Bliskiego Wschodu. Istotny wyjątek stanowić może tutaj jedynie rola namiestnika haremu, która w bizantyńskiej tradycji nie była w ogóle obecna. Eunuchów odnajdujemy często jako urzędników sprawujących różnorakie funkcje dyplomatyczne, administracyjne, wojskowe i religijne. W wielu przypadkach potrafili z powodzeniem łączyć kilka stanowisk. Niezwykła kariera rzezańców w Bizancjum, jaką możemy zaobserwować na przestrzeni dziejów cesarstwa, była wypadkową kilku czynników. Jednym z nich był z pewnością sposób sprawowania rządów przez bizantyńskich władców, zaczerpnięty w dużej mierze z wzorców orientalnych. Uwidaczniał się on zarówno w dworskim rytuale, jak i w zcentralizowanej, przesiąkniętej biurokratyzmem władzy. Jej zaś nieodłącznym elementem był również eunuch, który sprawował funkcję urzędnika na cesarskim dworze. Coraz większe zaufanie jakim zaczęto obdarzać rzezańców w Bizancjum jest najlepszym dowodem na to, iż świetnie sprawdzali się oni na powierzonych im stanowiskach. Na dworze bizantyńskim trzebieńcy sprawowali trzy zasadnicze funkcje. Pierwszą z nich była funkcja kościelna. Mogli oni być kapłanami, ale pod ściśle określonymi warunkami, które regulował odpowiedni kanon 1. Soboru Nicejskiego I (325). Czytamy w nim, że:

„Jeśli ktoś został okaleczony przez lekarzy podczas choroby lub wykastrowany przez barbarzyńców, ten niech pozostanie w gronie duchownych. Lecz ten, kto będąc dobrego zdrowia sam siebie pozbawił męskości, powinien zostać wykluczony z grona duchownych, do którego już należał. Od tej chwili nie należy wyświęcać żadnego z tych, którzy w ten sposób postępują. Jest jednak oczywiste, że to, co powiedziano wyżej, dotyczy tylko tych, którzy uczynili to celowo i którzy sami chcieli się okaleczyć. Ci co zostali okaleczeni przez

\footnotetext{
${ }^{24}$ Por. Ringrose, The Perfect Servant, s. 10.

${ }^{25}$ Por. Szumowski, O eunuchach $i$ kastracji, s. 21.

${ }^{26}$ Por. Herrin, Bizancjum, s. 199.
} 
barbarzyńców albo przez swoich panów, a uważani są za godnych, mogą, zgodnie z kanonem, zostać do stanu duchownego dopuszczeni"27.

Jednak de facto stosunek Kościoła do kastratów na Wschodzie i Zachodzie państwa rzymskiego różnił się w znaczący sposób. W Rzymie trzebieńcy nie dochodzili do wysokich stanowisk kościelnych. Inaczej sytuacja przedstawiała się we wschodniej części cesarstwa. Oprócz funkcji zwykłych kapłanów zajmowali oni tam także zaszczytne stanowiska biskupów i patriarchów, nierzadko z woli cesarzy przez których byli desygnowani. Kastraci mieli również wstęp do wspólnot monastycznych, a nawet często bywało tak, że pewne klasztorne stanowiska były przeznaczone specjalnie dla nich ${ }^{28}$. Rzezańcy pełnili także służbę w klasztorach żeńskich na wschodzie imperium, np. odprawiając Msze św. dla mniszek. Umieszczano ich tam mając na względzie zapewnienie kobietom, które poświęciły się służbie Bogu, życia w czystości ${ }^{29}$.

Drugą istotną grupę stanowili eunuchowie, którzy pełnili funkcje cywilne. Cesarze lubili się nimi otaczać i często mianowali ich na wysokie stanowiska publiczne. Byli znacznie lepszymi urzędnikami dlatego, że żaden eunuch, choćby nawet bardzo pragnął władzy i bogactwa, nie aspirował do tronu cesarskiego. Co więcej, w razie czego, gdy nie byli już potrzebni, mogli zostać usunięci z dworu bez żadnych większych konsekwencji, co nie mogło mieć miejsca $\mathrm{w}$ przypadku przedstawicieli bogatych i wpływowych rodów arystokratycznych $^{30}$. Ich popularność jednak miała przede wszystkim związek z ich przydatnością na danym stanowisku, a ta była zagwarantowana przez długie lata przygotowań do pełnionych funkcji.

Trzecią i ostatnią grupę stanowili eunuchowie służący w armii. Byli oni mile widziani na stanowiskach dowódczych i oficerskich z tego samego powodu, dla którego trzymani byli w najbliższym otoczeniu cesarza na dworze. Posiadanie bowiem dowództwa nad armią wiązało się z posiadaniem w swoich rękach realnej siły, a ta z kolei mogła stanowić olbrzymią pokusę dla generałów-uzurpatorów. W historii cesarstwa rzymskiego i Bizancjum znajdujemy wiele przykładów buntów wodzów armii, które niejednokrotnie kończyły się detronizacją panującego imperatora. Eunuchowie będący generałami być może nie cieszyli się specjalną sympatią i szacunkiem żołnierzy, ale stanowili dla cesarzy właśnie ten niezwykle ważny „,bufor bezpieczeństwa”, chroniący ich przed spiskami kadry dowódczej. Oprócz Narzesa znanym rzezańcem sprawującym znaczącą funkcję w wojsku bizantyjskim za Justyniana był Salomon, dowódca wojsk Afryki Północnej (rzymskiej), który zginął w 544 r.

${ }^{27}$ Concilium Nicaenum I (325) can. 1, w: ŹMT 24 [wydanie grecko-łacińsko-polskie, układ i opr. A. Baron - H. Pietras, thum. T. Wnętrzak], Kraków 2001 = DSP 1, 27.

${ }^{28}$ Por. Guilland, Les eunuques dans l'Empire Byzantin, s. 205.

${ }^{29}$ Por. Szumowski, O eunuchach i kastracji, s. 17.

${ }^{30}$ Taki los spotkał m.in. eunucha Antiocha, który doszedł do bardzo wysokich funkcji za rządów cesarza Teodozjusza II (408-450), por. G. Greatrex - J. Bardill, Antiochus the „Praepositus ”: A Persian Eunuch at the Court of Theodosius II, DOP 50 (1996) 171-197. 
w bitwie pod Cillium ${ }^{31}$, oraz Scholasticus, który był jednym z dowódców armii walczącej z najazdem Sklawinów w roku $551^{32}$. Również imiona innych eunuchów w kontekście prowadzonych przez cesarstwo wojen pojawiają się w źródłach nader często i to przez cały okres jego istnienia, aż do upadku w połowie $\mathrm{XV}$ wieku ${ }^{33}$.

2. Kariera Narzesa na dworze cesarza Justyniana. Chyba najbardziej znanym bizantyjskim eunuchem był Narzes ${ }^{34}$, który w VI w., za panowania cesarza Justyniana, doszedł do najwyższych urzędów we wschodnim cesarstwie $^{35}$. Znaczną część wiedzy na temat jego życia i dokonań czerpiemy od Prokopiusza z Cezarei (ok. 500-562), dziejopisa, który był sekretarzem innego wielkiego bizantyńskiego wodza, Belizariusza (ok. 505-565). W swojej Historii wojen Prokopiusz skupia się - rzecz jasna - na militarnych aspektach dokonań eunucha. Narzes, chociaż najbardziej znany właśnie jako wódz bizantyńskiej armii w służbie cesarza Justyniana, spełniał na konstantynopolitańskim dworze również szereg innych, niemniej ważnych funkcji. Pochodzenie i okres młodości rzezańca są owiane tajemnicą i stanowią temat dociekań badaczy ${ }^{36}$.

Narzes urodził się prawdopodobnie ok. roku 480 lub 490 ${ }^{37}$. Można przypuszczać, że pochodził z obszaru perskiej Armenii, na co wskazuje jego imię, które jest wyraźnie pochodzenia wschodniego ${ }^{38}$. Nie wiadomo kiedy dokładnie rzezaniec przybył do Konstantynopola. Prawdopodobnie pochodził z niskich warstw społecznych, a do stolicy przybył jako niewolnik. Nie posiadamy również informacji na temat tego, w jaki sposób trafił na cesarski dwór, ani jak przedstawiała się ścieżka jego kariery w początkowej fazie. Agatiasz (ok. 530582) pisze, iż Narzes nie był człowiekiem dobrze wykształconym ani w sztu$\mathrm{ce}$, ani w retoryce, jednak posiadał bardzo przenikliwy i bystry umys ${ }^{39}$. Ten

${ }^{31}$ Por. Procopius Caesariensis, Bella IV 21, 28, ed. J. Haury, vol. 1, Lipsiae 1963, 522, 2-5, thum. D. Brodka: Prokopiusz z Cezarei, Historia wojen, t. 1, Kraków 2013, 337.

${ }^{32}$ Por. M.E. Stewart, The Andreios Eunuch-Commander Narses: Sign of a Decoupling of Martial Virtues and Masculinity in the Early Byzantine Empire?, „Ceræ” 2 (2015) 2.

${ }^{33}$ Por. Guilland, Les eunuques dans l'Empire Byzantin, s. 205-214.

${ }^{34}$ Narzesowi została poświęcona jedna monografia oraz szereg rozdziałów w kilku opracowaniach dotyczących rządów Justyniana Wielkiego, por. R. Browning, Justynian i Teodora, thum. M. Boduszyńska-Borowikowa, Warszawa 1977, 69-71; L.H. Fauber, Narses: Hammer of the Goths, New York 1990; J.A. Evans, Justynian i Imperium Bizantyjskie, tłum. B. Godzińska, Warszawa 2008, 150-154.

${ }^{35}$ Por. J.R. Martindale, Narses 1, PLRE III 912-928; J.H. Rosser, Historical Dictionary of Byzantium, Lanham 2001, 287.

${ }^{36}$ Por. Browning, Justynian i Teodora, s. 70; Evans, Justynian, s. 150; Stewart, The Andreios Eunuch-Commander Narses, s. 5.

${ }^{37}$ Por. A. Lippold, Narses, w: Der Kleine Pauly, III, München 1979, 1575-1577; P. Krupczyński, Narses, w: Encyklopedia kultury bizantyńskiej, red. O. Jurewicz, Warszawa 2002, 363-364.

${ }^{38}$ Por. Evans, Justynian, s. 150.

${ }^{39}$ Por. Agathias Myrinaeus, Historiarum libri quinque I 16, 1, ed. R. Keydell, CFHB Series Berolinensis 2, Berolini 1967, 30. 
sam obraz eunucha rysuje się w dziele Prokopiusza, który podaje informację, że Narzes był człowiekiem inteligentnym i dynamicznym, co nie było typowe w przypadku trzebieńców ${ }^{40}$. Źródła opisują też rzezańca jako człowieka drobnej i wattej postury ${ }^{41}$.

W zachowanych przekazach źródłowych eunuch ten pojawia się już jako osoba dojrzała, mająca pewną, ugruntowaną pozycję w najbliższym otoczeniu Justyniana. Można jednak domniemywać, że na początku swojej służby zajmował w pałacu niższe stanowiska urzędnicze. Być może był kimś w rodzaju nadwornego skarbnika (podskarbiego) ${ }^{42}$. W późniejszym okresie funkcjono-

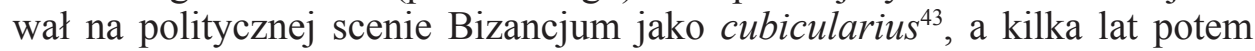
jako spatharius jest członkiem gwardii cesarskiej ${ }^{44}$. Być może właśnie wtedy eunuch zaskarbił sobie łaski cesarza $\mathrm{i}$ jego żony, co pozwoliło mu na szybki awans w pałacowej, urzędniczej hierarchii ${ }^{45}$. Niewykluczone, że cesarska para faworyzowała ludzi niższego stanu, gdyż sama z tego stanu się wywodziła ${ }^{46}$. Już krótko po przejęciu władzy przez Justyniana Narzes został wybrany dowódcą cesarskiej straży przybocznej, którą stanowili rzezańcy ${ }^{47}$. Swoją wysoką pozycję zawdzięczał prawdopodobnie umiejętności dostosowania się do aktualnej sytuacji na dworze i odpowiednim poglądom, politycznym i religijnym, którymi potrafił sobie zaskarbić przychylność najbardziej wpływowych osób w państwie. Przykładowo, cesarzową Teodorę (ok. 500-548) przekonał do siebie swoimi sympatiami monofizyckimi, z którymi jednak, jak przystało na wyrafinowanego dworskiego gracza, nie obnosił się ${ }^{48}$. Starał się w ten sposób nie zrazić do siebie innych wysoko postawionych urzędników w Konstantynopolu. Ta względna neutralność Narzesa połączona ze sprytem otworzyła mu drogę do błyskotliwej kariery.

${ }^{40}$ Por. Procopius Caesariensis, Bella VI 13, 16, ed. Haury, vol. 2, s. 208, 9-13, thum. Brodka, t. 2, s. 149.

${ }^{41}$ Por. Agathias Myrinaeus, Historiarum, I 16, 1, CFHB Series Berolinensis 2, 30.

${ }^{42}$ Por. Procopius Caesariensis, Bella VI 13, 16, ed. Haury, vol. 2, s. 208, 9-13, thum. Brodka, t. 2, s. 149. Por. Guilland, Les eunuques dans l'Empire Byzantin, s. 205.

${ }^{43}$ Cubicularius - tytuł, którego używano we wczesnym Bizancjum na określenie eunuchówszambelanów, których bezpośrednim zwierzchnikiem był praepositus sacrii cubiculi, por. Barnwell, Emperor, Prefects, and Kings, s. 20; G. Ostrogorski, Dzieje Bizancjum, tłum. W. Ceran - H. EvertKappesowa - S. Wiśniewski, Warszawa $2008^{3}, 78$.

${ }^{44}$ Spatharius - tytuł odnoszący się do członków przybocznej cesarskiej straży bizantyńskiej. Często zatrudniano w niej eunuchów będących cubicularii, por. M. Whitby, On the Omission of a Ceremony in Mid-Sixth Century Constantinople: Candidati, Curopalatus, Silentiarii, Excubitores and Others, ,Historia” 36 (1987) 467.

${ }^{45}$ Por. P. Cesaretti, Teodora, thum. B. Bielańska, Warszawa 2003, 149.

${ }^{46}$ Por. T. Wolińska, Zwiazki rodzinne w polityce personalnej Justyniana I, „Acta Universitatis Lodziensis. Folia Historica” 67 (2000) 23-24; P. Kochanek, Chorycjusz z Gazy i jego „Obrona mimów” rozumiana jako kryptoapologia cesarzowej Teodory, „Res Historica” 36 (2013) 40-41, 44, 46-47 i 53.

${ }^{47}$ Por. Browning, Justynian i Teodora, s. 70.

${ }^{48}$ Por. Evans, Justynian, s. 151. 
$\mathrm{Na}$ początku $532 \mathrm{r}$. Armeńczyk odegrał bardzo istotną rolę w thumieniu tzw. powstania Nika ${ }^{49}$, które wstrząsnęło Konstantynopolem i o mało nie pozbawiło Justyniana tronu. Eunuch początkowo został wysłany do przywódców rewolty. Miał za zadanie przy pomocy łapówek, przekupstwa i namawiania, wyłączyć z powstania frakcję niebieskich ${ }^{50}$. Rzezaniec chciał ich przekonać, że prędzej czy później zieloni wypomną im wcześniejsze konflikty i będą dążyć do konfrontacji. Fakcja ta bowiem przed wybuchem powstania cieszyła się wsparciem administracji cesarskiej, a sam Justynian nie ukrywał swoich „pro-niebieskich” sympatii ${ }^{51}$. Zabiegi Narzesa przyniosły tylko częściowy sukces, tak że ostatecznie cesarz za namową Teodory zdecydował się użyć wojska pod wodzą dwóch generałów, Mundusa († ok. 536) i Belizariusza ${ }^{52}$, do zdławienia rebelii. Mimo że taktyka polegająca na napuszczaniu przeciwko sobie stronnictw nie przyniosła zamierzonego rezultatu, eunuch wiele zyskał tymi zabiegami w oczach Justyniana. Podczas ataku oddziałów pod dowództwem Belizariusza i Mundusa, Narzes razem ze swoimi podkomendnymi uczestniczył w pacyfikacji ludu, który zgromadził się w hipodromie i obrał nowym cesarzem Hypacjusza $(† 532)^{53}$, siostrzeńca cesarza Anastazjusza (491518). Jego ludzie mieli blokować drogę ucieczki próbującym się wymknąć ze stadionu rebeliantom. Lojalność Narzesa w tym krytycznym momencie panowania sprawiła, że zarówno Justynian jak i Teodora obdarzyli go dozgonną wdzięcznością. Pokazał też wówczas, że dowodzenie sporym oddziałem wojskowym nie jest mu obce i że potrafi dobrze wywiązać się z takiego zadania.

W ciagu kolejnych paru lat Narzes prawdopodobnie bardzo intensywnie studiował arkana sztuki wojennej, zasięgając przy tym rad wielu doświadczonych wodzów i generałów. Nowo nabyte umiejętności miały mu się wkrótce przydać podczas kolejnej misji, tym razem zleconej przez cesarzową Teodorę. Eunuch miał udać się na czele silnego oddziału do Egiptu, aby tam wesprzeć Teodozjusza (†567), faworyta cesarzowej, i umocnić jego władzę patriarchy Aleksandrii ${ }^{54}$. Jednak sukces, który udało się osiągnąć Narzesowi nad Nilem, był krótkotrwały. W Aleksandrii wybuchła bowiem rewolta, której eunuch nie

${ }^{49}$ Por. tamże, s. 150. Więcej na temat powstania Nika, por. J.B. Bury, The Nika Riot, „Journal of Hellenic Studies” 17 (1897) 92-119; J.E. Atkinson, The Nika Riots and 'Hooliganism', „Acta Patristica et Byzantina" 1 (1990) 119-133; S.G. Giatsis, The Massacre in the Riot of Nika in the Great Hippodrome of Constantinople in 532 A.D., „International Journal of the History of Sport” 12 (1995) 141-152; Evans, Justynian, s. 57-64; N. Westbrook, The Account of the Nika Riot as Evidence for Sixth-century Constantinopolitan Typography, ,Journal of the Australian Early Medieval Association" 7 (2011) 33-54.

${ }^{50}$ Por. G. Greatrex, A Nika Riot: A Reappraisal, „Journal of Hellenic Studies” 117 (1997) 79.

${ }^{51}$ Por. J.W. Barker, Justinian and the Later Roman Empire, Madison - London 1966, 84.

52 Por. Procopius Caesariensis, Bella I 24, 52, ed. Haury, vol. 1, s. 132, 23 - 133, 4, thum. Brodka, t. 1, s. 89-90.

${ }^{53}$ Por. tamże I 24, 22, ed. Haury, vol. 1, s. 127, 21-25, thum. Brodka, t. 1, s. 86.

${ }^{54}$ Por. H. Leppin, Poczatki polityki kościelnej Justyniana, tłum. K. Ilski-A. Kotłowska, Poznań 2005, 19. 
potrafił zdławić. W konsekwencji był zmuszony wraz z wojskiem wycofać się $\mathrm{z}$ Egiptu $^{55}$. To niepowodzenie nie miało jednak znaczącego wpływu na przebieg jego kariery.

Z kolei w 538 r. Armeńczyk został wysłany na czele silnego, liczącego 7 tys. żołnierzy kontyngentu do Italii, aby wesprzeć tam działania Belizariusza, który przebywał na Półwyspie Apenińskim już od dłuższego czasu ${ }^{56}$. Bardzo możliwe, że eunuch dostał od Justyniana dodatkowe wytyczne, zgodnie z którymi miał kontrolować poczynania trackiego generała, któremu cesarz nie do końca ufał. Spory kompetencyjne i osobiste animozje pomiędzy Narzesem a Belizariuszem doprowadziły do kilku militarnych niepowodzeń. W tej sytuacji Justynian był zmuszony odwołać Narzesa do Konstantynopola, aby przywrócić w Italii jednolitość dowodzenia ${ }^{57}$.

W kolejnych latach Narzes mocno przysłużył się Teodorze w trakcie przepychanek pałacowych, mających na celu usunięcie z zajmowanych stanowisk kilku wpływowych urzędników, którzy swego czasu narazili się cesarzowej ${ }^{58}$. Brał m.in. udział $\mathrm{w}$ spisku, który miał na celu usunięcie $\mathrm{z}$ administracji cesarskiej jednego z najbardziej wpływowych ludzi w Bizancjum, Jana z Kapadocji $^{59}$. Dzięki intrydze, w której uczestniczył, udało się cesarzowej zmusić męża do odwołania tego urzędnika.

W późniejszych latach Narzes dość poważnie rozważał odejście ze świata wielkiej polityki. W latach 40 -tych był człowiekiem już po sześćdziesiątce i powoli zaczynał skupiać się na kwestiach duchowych. Prawdopodobnie myślał również o wstąpieniu do klasztoru, by tam w ciszy i spokoju dokonać żywota $^{60}$. Jego plany musiały jednak ulec zmianie z powodu coraz bardziej komplikującej się sytuacji w Italii. Gocka kontrofensywa zakończyła się bowiem zdobyciem Rzymu na początku 550 r. Aby ratować swoje plany restauracji Imperium na Półwyspie Apenińskim cesarz zorganizował nowy silny kontyngent, pod wodzą swojego kuzyna Germanusa, który miał zostać wysłany do walki z barbarzyńcami. Nieoczekiwanie jednak nowo obrany wódz zmarł po krótkiej

${ }^{55}$ Nie ma pewności, czy rzeczywiście dowódcą wysłanym do Egiptu przez cesarzową Teodorę był ten czy inny Narzes. Niektórzy naukowcy zwracają uwagę, że najprawdopodobniej chodzi o innego eunucha, także dowódcę wojskowego o tym samym imieniu. Warto zauważyć, że imię Narzes było popularne wśród Armeńczyków przybywających do Bizancjum w tym okresie. Istnieje również koncepcja, zgodnie z którą w owym czasie w Egipcie przebywali dwaj urzędnicy cesarscy o tym samym imieniu, por. E.R. Hardy, The Egyptian Policy of Justinian, DOP 22 (1968) 33; M.W. Kruse, Narses and the Birth of Byzantine Egypt: Imperial Policy in the Age of Justinian, Richmond 2008 (Honors Theses), 4-5.

${ }^{56}$ Por. Procopius Caesariensis, Bella VI 13, 16, ed. Haury, vol. 2, s. 208, 9-10, thum. Brodka, t. 2, s. 149 .

${ }^{57}$ Por. tamże VI 22, 4, ed. Haury, vol. 2, s. 247, 17-21, thum. Brodka, t. 2, s. 172.

${ }^{58}$ Por. Evans, Justynian, s. 151.

${ }^{59}$ Por. Procopius Caesariensis, Bella I 25, 26, ed. Haury, vol. 1, s. 139, 2-7, thum. Brodka, t. 1, s. 93.

${ }^{60}$ Narzes miał ufundować klasztor w Bitynii pod nazwą Rupis, który wspierał regularnymi datkami, por. Evans, Justynian, s. 151. 
chorobie, praktycznie $\mathrm{w}$ przededniu planowanej wyprawy ${ }^{61}$. Cesarz musiał w krótkim czasie znaleźć zaufanego następcę. Wybór padł właśnie na Narzesa.

W dwóch krwawych bitwach, pod Busta Gallorum, w okolicach Tadinum, i Mons Lactarius eunuchowi udało się rozbić siły Gotów ${ }^{62}$. Potem jeszcze sędziwy wódz zadał klęskę przesuwającym się na południe oddziałom Alemanów, którzy przybyli ze spóźnioną dla nich odsieczą ${ }^{63}$. Po usunięciu barbarzyńskiego zagrożenia rozpoczął się długi i żmudny proces przywracania rzymskiej administracji na terenie Italii. W tym czasie Narzes sprawował faktyczną władzę cywilną na Półwyspie Apenińskim, otrzymując od Justyniana w charakterze nagrody tytuł patrycjuszowski. Dał się poznać wtedy jako świetny zarządca i budowniczy. Eunuch wyruszając do Italii miał pod swoją komendą liczna, dobrze wyszkoloną armię, ale to w żadnej mierze nie umniejsza jego umiejętności dowódczych i geniuszu taktycznego. Pewnych istotnych informacji na temat osobowości Narsesa dostarcza nam Prokopiusz z Cezarei w VIII księdze swojej Historii Wojen:

„Był więc Narzes człowiekiem bardzo szczodrym, nader skłonnym do tego, by uczynić coś dobrego dla tych, którzy czegoś potrzebowali. Gdy zaś otrzymał od cesarza wielką władzę, bez większego skrępowania koncentrował się na tym co go interesowało. Stąd już wcześniej dla wielu dowódców i żołnierzy okazał się dobroczyńca. Kiedy został wyznaczony na wodza przeciw Totili i Gotom, wszyscy z wielką gorliwością pragnęli walczyć pod jego dowództwem: jedni, aby się odwdzięczyć za dawne łaski, inni, co naturalne, licząc, że otrzymają od niego wielkie nagrody. Szczególnie przychylnie byli nastawieni do niego Herulowie i inni barbarzyńcy, gdyż doznawali z jego strony dobrego traktowania" ${ }^{\prime 64}$.

W opisie tym rysuje się obraz człowieka dobrodusznego i lojalnego, cieszącego się sympatią swoich podwładnych. Na polu walki Narzes wykazywał się dużą odwaga, czy wręcz heroizmem ${ }^{65}$, a decyzje przez niego podejmowane nie były dyktowane emocjami, lecz chłodnym osądem ${ }^{66}$. Żołnierzom

${ }^{61}$ Por. Procopius Caesariensis, Bella VII 37, 24, ed. Haury, vol. 2, s. 466, 16-22, tłum. Brodka, t. 2, s. 302. Zob. E. Zwolski, Kasjodor i Jordanes. Historia gocka czyli scytyjska Europa, Lublin $1984,70$.

${ }^{62}$ Por. Procopius Caesariensis, Bella VIII 21, 19, ed. Haury, vol. 2, s. 602, 23-25, thum. Brodka, t. 2, s. 386. Zob. Z.V. Udalcova, La campagne de Narsès et l'écrasement de Totila, „Corsi di Cultura sull'Arte Ravennate e Bizantina” 18 (1971) 557-564; H.R. Roisl, Totila und die Schlacht bei den Busta Gallorum, Ende Juni/Anfang Juli 552, JÖB 30 (1981) 25-50; Zwolski, Kasjodor I Jordanes, s. 80; L. Carnevale, Totila come perfidus rex tra storia e agiografia, VetCh 40 (2003) 43-69; $\mathrm{Ph}$. Rance, Narses and the Battle of Taginae (Busta Gallorum) 552: Procopius and the Sixth-century Warfare, „Historia” 54 (2005) 424-472; G. Harward, A Defensive Offense: Infantry Tactics of the Early Byzantine Army, ,Studia Antiqua” 7 (2009) nr 1, 52-53.

${ }^{63}$ Por. J. Strzelczyk, Goci-rzeczywistość i legenda, Warszawa 1984, 150.

${ }^{64}$ Procopius Caesariensis, Bella VIII 26, 14-17, ed. Haury, vol. 2, s. 632, 11-23, thum. Brodka, t. 2, s. 402-403.

${ }^{65}$ Por. Agathias Myrinaeus, Historiarum libri I 16, 1, CFHB Series Berolinensis 2, 30.

${ }^{66}$ Por. tamże I 12, 4, CFHB Series Berolinensis 2, 24. 
pokonanych barbarzyńskich armii okazywał miłosierdzie, nie pozwalając, by stała im się jakakolwiek krzywda ${ }^{67}$.

Nie ma pewności co do daty śmierci Narzesa. Wiadomym jest, że przeżył o kilka lat Justyniana, który zmarł w 565 r. Jedni badacze uważają, że dokonał on żywota w Rzymie w 568 r., inni podają za datę jego śmierci rok $575^{68}$. Eunuch miał w momencie zgonu ok. 95 lat. Ciało Narzesa sprowadzono do Konstantynopola i złożono w klasztorze, który ufundowa ${ }^{69}$.

Ścieżka kariery Narzesa dobitnie pokazuje, że był on człowiekiem niezwykle uzdolnionym i potrafiącym w bardzo umiejętny sposób lawirować pomiędzy różnymi wzajemnie zwalczającymi się fakcjami na bizantyńskim dworze. Pozwalało mu to przez długie lata cieszyć się dużym zaufaniem cesarza i jego małżonki, i wspiąć się na szczyt urzędniczej hierarchii.

$Z$ drugiej strony postać Narzesa jest przykładem wyjątkowej kariery rzezańca, która była możliwa nie przypadkiem w okresie panowania Justyniana. W pewnym sensie to rozmach polityczno-militarnych planów tego cesarza wyniósł Narzesa na wspomniany wyżej szczyt. W ten sposób czas, miejsce oraz indywidualne zdolności i ambicje stworzyły określoną jedność, która stała się trampoliną dla kariery skromnego skądinąd trzebieńca. Narzesa należy więc uważać za tzw. dziecko swoich czasów. Jednak, co ciekawe, miejsca na kartach historii nie zapewnił mu udział w dworskich intrygach zwalczających się wzajemnie koterii, lecz dowództwo w wojnie z Gotami. To przecież on rozgromił ostatecznie wojska tej nacji, powodując, że Ostrogoci znikli de facto z kart historii. Dało mu to miejsce w panteonie wielkich wodzów wczesnego Bizancjum i sprawiło, że jego imię przetrwało na kartach historii w aureoli wojennej chwały, a nie naznaczone piętnem małego dworskiego intryganta.

\section{THE ROLE OF EUNUCHS IN BYZANTINE COURTS. THE CASE OF NARSES}

\section{(Summary)}

The article is divided into two sections. First presents the role of eunuchs in Byzantine Empire in general. Second section focuses specifically on Narses, his life, main achievements and legacy.

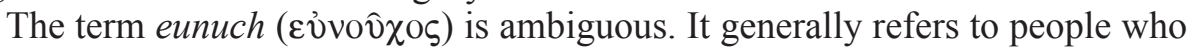
are not able to procreate due to natural constitution or mutilation, but it can have many various meanings. It can also refer to the man who is absent from procreation

${ }^{67}$ Por. tamże II 14, 7, CFHB Series Berolinensis 2, 58.

${ }^{68}$ Narzes zmarł na pewno po roku 567, kiedy to przeniósł się z Rawenny do Rzymu. Zmiana miejsca pobytu eunucha mogła mieć związek z dymisją jakiej miał udzielić mu nowy cesarz Justyn II (565-578), por. Guilland, Les eunuques dans l'Empire Byzantin, s. 205; Browning, Justynian i Teodora, s. 71; K. Zakrzewski, Historia Bizancjum, Kraków 2007, 89.

${ }^{69}$ Por. Evans, Justynian, s. 154. 
due to impotence or celibate. For people who has been born incapacitated or with some hormonal anomalies we use term ,natural eunuchs”.

There were several functions of eunuchs in Byzantine state we can differentiate. First is religious. Eunuchs were present in institution of Church from the very beginning. They could have been priests and patriarchs if they did not become eunuchs as a result of self-mutilation. Many eunuchs were high officials at the court of Byzantine emperors. They served as envoys, agents and as a members of palace guard. They were also responsible for superintending of the emperor's son. And finally, eunuchs were successful and talented military leaders.

Life of Narses is fascinating example of a great career of eunuch in Byzantine Empire. He owes his success to his many talents and sympathy and protection of the emperor Justinian and his wife Theodora. He came to Constantinople from east, probably as a slave. At the beginning, he was a low rank official at the court. $\mathrm{He}$ also served as a member of the palace guard. Thanks to his intelligence and flexibility he became chamberlain at the court. Later he got a generalship of Byzantine army in Italy. He was called back to the capital, after he got involved in conflict with great general Belisarius. Several years later, however, Justinian once again used his skills to finally crush Ostrogoth's army. He spent his last years of life as governor of conquered land.

Key words: Byzantine Empire, eunuch, Narses.

Słowa kluczowe: Bizancjum, eunuch, Narzes.

\section{BIBLIOGRAFIA}

\section{Źródła}

Agathias myrinaeus, Historiarum libri quinque, ed. R. Keydell, CFHB Series Berolinensis 2, Berolini 1967.

Concilium Nicaenum I (325), Canones, w: ŹMT 24 [wydanie grecko-łacińsko-polskie, układ i opr. A. Baron - H. Pietras, tłum. T. Wnętrzak], Kraków 2001 = DSP 1, 24-61.

Procopius Caesariensis, Bella, ed. J. Haury, vol. 1-2, Lipsiae 1963, thum. D. Brodka: Prokopiusz z Cezarei, Historia Wojen, t. 1-2, Kraków 2013-2015.

\section{Opracowania}

AtKinson J.E., The Nika Riots and 'Hooliganism', „Acta Patristica et Byzantina” 1 (1990) 119-133.

BARKER J.W., Justinian and the Later Roman Empire, Madison - London 1966.

Barnwell P.S., Emperor, Prefects, and Kings: Roman West, 395-565, London 1992.

BRowning R., Justynian i Teodora, tłum. M. Boduszyńska-Borowikowa, Warszawa 1977. Bury J.B., The Nika Riot, ,Journal of Hellenic Studies” 17(1897) 92-119.

CANER D.F., The Practice and Prohibition of Self-castration in Early Christianity, VigCh 51 (1997) 396-415.

Carnevale L., Totila come perfidus rex tra storia e agiografia, VetCh 40 (2003) 43-69.

Cesaretti P., Teodora, tłum. B. Bielańska, Warszawa 2003.

Cilliers L. - Retief F.P., The Eunuchs of Early Byzantium, „Scholia” 13 (2004) 108-117. 
Coser L.A., The Political Functions of Eunuchism, „American Sociological Review” 6 (1964) 880-885.

EL-CHEIKH N.M., Servants at the Gate: Eunuchs at the Court of Al-Muqtadir, „Journal of the Economic and Social History of the Orient" 48 (2005) 234-252.

Evans J.A., Justynian i Imperium Bizantyjskie, tłum. B. Godzińska, Warszawa 2008.

FAuBER L.H., Narses: Hammer of the Goths, New York 1990.

Giatsis S.G., The Massacre in the Riot of Nika in the Great Hippodrome of Constantinople in 532 A.D., „International Journal of the History of Sport” 12 (1995) 141-152.

Greatrex G., A Nika Riot: A Reappraisal, „Journal of Hellenic Studies” 117(1997) 60-86.

Greatrex G. - Bardill J., Antiochus the „Praepositus”: A Persian Eunuch at the Court of Theodosius II, DOP 50 (1996) 171-197.

Guilland R., Les eunuques dans l'Empire Byzantin: Étude de titulature et de prosopographie byzantines, EtByz 1 (1943) 197-238.

Hardy E.R., The Egyptian Policy of Justinian, DOP 22 (1968) 21-41.

Harward G., A Defensive Offense: Infantry Tactics of the Early Byzantine Army, „Studia Antiqua" 7 (2009) nr 1, 45-54.

Haussig H.-W., Historia kultury bizantyńskiej, tłum. T. Zabłudowski, Warszawa 1969.

Herrin J., Bizancjum. Niezwykte dziedzictwo średniowiecznego imperium, thum. N. Radomski, Poznań 2009.

Hopkins K., Eunuchs in Politics in the Later Roman Empire, „Cambridge Classical Journal" 9 (1963) 62-80.

JONCKHEERE F., L'Eunuque dans l'Égypte pharaonique, „Revue d'Histoire des Sciences” 7 (1954) 139-155.

Kochanek P., Chorycjusz z Gazy i jego „,Obrona mimów” rozumiana jako kryptoapologia cesarzowej Teodory, „Res Historica” 36 (2013) 31-53.

Konstantynopol - Nowy Rzym. Miasto i ludzie w okresie wczesnobizantyńskim, red. M.J. Leszka - T. Wolińska, Warszawa 2011.

KRUPCZYŃski P., Narses, w: Encyklopedia kultury bizantyńskiej, red. O. Jurewicz, Warszawa 2002, 363-364.

Kruse M.W., Narses and the Birth of Byzantine Egypt: Imperial Policy in the Age of Justinian, Richmond 2008 (Honors Theses).

Lalou E., Chambellan, w: Lexikon des Mittelalters, II, München 1983, 1671.

Leprin H., Poczatki polityki kościelnej Justyniana, tłum. K. Ilski - A. Kotłowska, Poznań 2005.

Lippold A., Narses, w: Der Kleine Pauly, III, München 1979, 1575-1577.

Martindale J.R., Narses 1, PLRE III 927-928.

Ostrogorski G., Dzieje Bizancjum, tłum. W. Ceran-H. Evert-Kappesowa-S. Wiśniewski, Warszawa $2008^{3}$.

Rance Ph., Narses and the Battle of Taginae (Busta Gallorum) 552: Procopius and the Sixth-century Warfare, „Historia” 54 (2005) 424-472.

Ringrose K., The Perfect Servant: Eunuchs and the Social Construction of Gender in Byzantium, Chicago 2003.

Ringrose K., Eunuchs in Historical Perspective, „History Compass” 5 (2007) 495-506.

Roisl H.R., Totila und die Schlacht bei den Busta Gallorum, Ende Juni/Anfang Juli 552, JÖB 30 (1981) 25-50.

Roller L.E., The Ideology of the Eunuch Priest, „Gender \& History” 9 (1997) 542-559.

Rosser J.H., Historical Dictionary of Byzantium, Lanham 2001.

Stevenson W., The Rise of Eunuchs in Greco-Roman Antiquity, ,Journal of the History of Sexuality" 5 (1995) 495-511. 
Stewart M.E., The Andreios Eunuch-Commander Narses: sign of a decoupling of martial virtues and masculinity in the early byzantine Empire?, „Ceræ” 2 (2015) 1-25.

StrzelczyK J., Goci-rzeczywistość i legenda, Warszawa 1984.

Szram M., Autokastracja Orygenesa - fakt czy nieporozumienie?, VoxP 23 (2003) t. 4445, 171-202.

SzUMOWski W., O eunuchach i kastracji w różnych krajach i czasach oraz kilka drobnych artykułów, Kraków 1946.

Toledano E.R., The Imperial Eunuchs of Istanbul: From Africa to the Heart of Islam, „Middle Eastern Studies” 20 (1984) 379-390.

Tougher S., The Eunuch in Byzantine History and Society, London 2008.

Tracy L., Introduction: A History of Calamites: The Culture of Castration, w: Castration and Culture in the Middle Ages, ed. L. Tracy, Cambridge 2013, 1-28.

Tsai S.H., The Eunuchs in the Ming Dynasty, New York 1996.

Udalcova Z.V., La campagne de Narsès et l'écrasement de Totila, „Corsi di Cultura sull'Arte Ravennate e Bizantina" 18 (1971) 557-564.

Westbroor N., The Account of the Nika Riot as Evidence for Sixth-century Constantinopolitan Typography, ,Journal of the Australian Early Medieval Association” 7 (2011) 33-54.

Whitby M., On the Omission of a Ceremony in Mid-Sixth Century Constantinople: Candidati, Curopalatus, Silentiarii, Excubitores and Others, „Historia” 36 (1987) 462-488.

Wolińska T., Zwiazki rodzinne w polityce personalnej Justyniana I, „Acta Universitatis Lodziensis. Folia Historica" 67 (2000) 23-44.

ZAKrZEwski K., Historia Bizancjum, Kraków 2007.

ZwolsKi E., Kasjodor i Jordanes. Historia gocka czyli scytyjska Europa, Lublin 1984. 
